\title{
放射音を用いた CFRP 積層板の実験的衝撃荷重同定*1 Experimental Identification of Impact Forces Acting on CFRP Laminated Plates Using Radiated Sounds
}

\author{
跡 部 哲 士*2 · 小 林 洸 貴*2 ·胡寧*3 福 永 久 雄*2
}

Satoshi Atobe, Hirotaka Kobayashi, Ning Hu and Hisao Fukunaga

Key Words : Identification Method, Impact Location, Force History, Sound Pressure

\begin{abstract}
In this paper, a method for identifying an impact force acting on a CFRP laminated plate is proposed. The location and force history of the impact force are identified using the sound radiation from the impacted plate. Microphones are used to measure the sound pressures at multiple locations. The impact location is identified from the arrival times of the sound wave to the microphones. For the force history identification, experimental transfer matrices which relate the impact force and the measured sound pressures are used. The force history is identified by minimizing the deviation between the measured and estimated sound pressures where the estimated ones are obtained using the experimental transfer matrices. The validity of the proposed method is verified experimentally by performing impact force identification of CFRP laminated plates. In addition, the effect of background noise on the accuracy of the identification results is also examined. The results reveal that the proposed method is capable of accurately identifying the impact location and force history from the radiated sound.
\end{abstract}

\section{1. 緒言}

航空機構造には，その製造，運用，整備点検などのあらゆ る過程において，異物衝突による衝撃荷重を受ける可能性 がある. 衝撃荷重は, 構造物に損傷を生じさせて構造健全性 を損なわせる危険性があり，重大な事故の原因となりうる。 特に, 様々な工業分野で構造物の軽量化が厳しく要求される 昨今に扔いて, 構造材料としての適用範囲が拡大している 炭素繊維強化プラスチック $(\mathrm{CFRP})$ などに代表される先進 複合材料は, 従来の金属材料と比へて比強度・比剛性といっ た点に扔いて優れた機械的特性を有する一方で, 主に一方 向強化材を重ね合わせて製造される複合材構造は, 衝撃荷 重に弱く, 外見上識別困難な衝撃損傷が容易に生じる ${ }^{11}$. 構 造物にセンサを内蔵して実時間で衝撃荷重のモニタリング ができれば，運用中における構造物の安全性・信頼性を保 証するにあたって有用な荷重位置・荷重履歴の情報が得ら れる。そこで, 衝撃荷重同定が重要な研究課題となる。

一般的に衝撃荷重の直接計測は困難であるため, 衝撃荷 重同定に関する従来の多くの同定手法では，センサで計 測した構造物の動的応答から逆解析で衝撃荷重を推定す る間接的手法が用いられている21. 衝撃荷重同定に用いる センサとしては, 構造物に貼付または埋め込まれたひずみ ゲージ3 5), 加速度計 ${ }^{6 \sim 9)}$, 圧電素子10 17), 光ファイバセ ンサ18,19) などが用いられてきた。これらのセンサは衝撃

\footnotetext{
*1 (C) 2013 日本航空宇宙学会

平成 24 年 11 月 3 日原稿受付

*2 東北大学大学院工学研究科航空宇宙工学専攻

*3 千葉大学大学院工学研究科人工システム科学専攻
}

応答の計測には適しているが, 構造物に内蔵して衝撃荷重 を実時間でモニタリングする場合, 構造物の剛性特性・強 度特性に及ぼす影響や，貼付・埋め込及可能位置の制約， センサの補修の困難さなどが久点になる。そこで，非接 触型センサを用いた衝撃荷重同定法の確立も必要となる。 辻ら 20 23) はマイクロホンで計測した振動放射音を計測情 報として用いる同定法を提案している. 文献 20)において は，予備実験を行って決定した衝撃力と放射音を関係づけ る伝達関数を用いた荷重履歴同定法を, 文献 21) に打いて は, 有限要素解析により求めた関倸性に基づく荷重履歴同 定法を報告している.また, 文献21) の同定法を発展させて アルミニウム平板に衝撃体（アルミニウム棒）が衝突した 際の衝撃位置や荷重履歴などの同定を行っている ${ }^{22,23)}$.

構造物に作用した衝撃荷重に関する情報を多く含み，かつ 非接触型センサであるマイクロホンで計測可能な振動放射音 は，衝撃荷重同定に用いる計測情報として有望である。しか し，これまでに報告されている同定法23)では，構築できる有 限要素モデルの精度に同定精度が大きく依存し，同定作業で 行う繰り返し計算も同定所要時間の長時間化につながると考 えられる。 そこで本研究では, 放射音圧を用いた衝撃荷重の 位置·荷重履歴の実験的同定法を提案する。本同定法は, 衝撃 荷重の作用位置から各マイクロホンに放射音が到達するまで の時間差より荷重位置を同定する。 そして, 荷重位置同定後, 衝撃荷重と音圧の計測值を関係づける実験的変換行列 24$) に$ 基づいた手法で荷重履歴同定を行う。まず，CFRP 積層板 を対象として静寂な実験室内で衝撃荷重同定実験を行い, 本同定法の妥当性を検証する，次に，ホワイトノイズを加 えた音圧計測情報を用いることで，騷音環境下に扔ける荷 
重位置・荷重履歴の同定精度について検討する.

\section{2. 実験的衝撃荷重同定法}

2.1 荷重履歴一音圧履歴の変換行列 第 1 図に面外方 向から衝撃荷重が作用する CFRP 積層板を示す. 座標系 としては, $x-y$ 平面が積層板の上面と一致するような直 交座標系 $(x, y, z)$ を採用する。衝撃荷重 $f(t)$ は積層板 上の点 $\left(x_{\mathrm{F}}, y_{\mathrm{F}}, 0\right)$ に垂直に作用するものとし，放射音を $I(\geq 3)$ 個のマイクロホンで計測する。 このとき, $i$ 番目マ イクロホンの計測位置 $\left(x_{\mathrm{S} i}, y_{\mathrm{S} i}, z_{\mathrm{S} i}\right)$ に抒ける音圧履歴 $\left\{\boldsymbol{p}_{i}\right\}$ と荷重履歴 $\{\boldsymbol{f}\}$ は次式のように関係づけられる.

$$
\left\{\boldsymbol{p}_{i}\right\}=\left[G_{i}\right]\{\boldsymbol{f}\}
$$

ただし，

$$
\begin{aligned}
& \left\{\boldsymbol{p}_{i}\right\}=\left[\begin{array}{llll}
p_{i}\left(t_{1}\right) & p_{i}\left(t_{2}\right) & \cdots & p_{i}\left(t_{N}\right)
\end{array}\right]^{\mathrm{T}}, \\
& \{\boldsymbol{f}\}=\left[\begin{array}{cccc}
f\left(t_{1}\right) & f\left(t_{2}\right) & \cdots & f\left(t_{N}\right)
\end{array}\right]^{\mathrm{T}}, \\
& {\left[G_{i}\right]=\left[\begin{array}{cccc}
g_{i, 1} & 0 & \cdots & 0 \\
g_{i, 2} & g_{i, 1} & \ddots & \vdots \\
\vdots & \vdots & \ddots & 0 \\
g_{i, N} & g_{i, N-1} & \cdots & g_{i, 1}
\end{array}\right]}
\end{aligned}
$$

ここで, $p_{i}\left(t_{n}\right)$ およよび $f\left(t_{n}\right)$ は, サンプリング間隔 $\Delta t_{\mathrm{s}}$ で 計測した時刻 $t_{n}=n \Delta t_{\mathrm{s}}(n=1, \cdots, N)$ に打ける音圧拉よ び荷重である。 $\left[G_{i}\right]$ は Green 関数により構成される変換 行列であり, 衝撃荷重の作用位置 $\left(x_{\mathrm{F}}, y_{\mathrm{F}}, 0\right)$ とセンサの位 置 $\left(x_{\mathrm{S} i}, y_{\mathrm{S} i}, z_{\mathrm{S} i}\right)$ によって決定される.

変換行列の成分からなるべクトル $\left\{\boldsymbol{g}_{i}\right\}$ を用いると式 (1) は次式のように表すことができる.

$$
\left\{\boldsymbol{p}_{i}\right\}=[F]\left\{\boldsymbol{g}_{\boldsymbol{i}}\right\}
$$

ただし，

$$
\begin{aligned}
&\left\{\boldsymbol{g}_{i}\right\}= {\left[\begin{array}{llll}
g_{i, 1} & g_{i, 2} & \cdots & g_{i, N}
\end{array}\right]^{\mathrm{T}}, } \\
& {[F]=\left[\begin{array}{cccc}
f\left(t_{1}\right) & 0 & \cdots & 0 \\
f\left(t_{2}\right) & f\left(t_{1}\right) & \ddots & \vdots \\
\vdots & \vdots & \ddots & 0 \\
f\left(t_{N}\right) & f\left(t_{N-1}\right) & \cdots & f\left(t_{1}\right)
\end{array}\right] } \\
& \text { Microphones } \\
&
\end{aligned}
$$

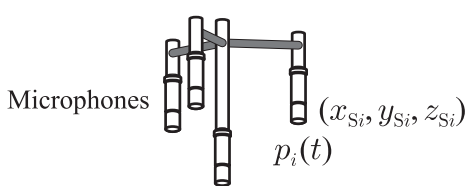

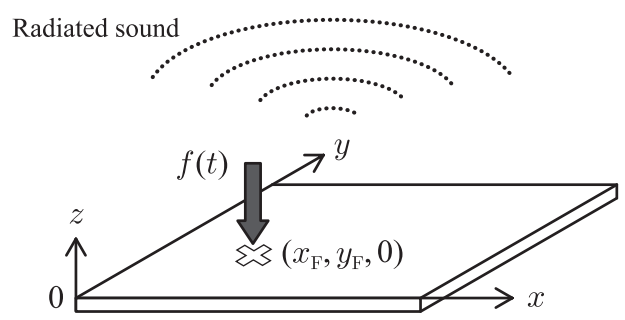

第1図衝撃荷重を受ける CFRP 積層板
変換行列の成分は，インパルスハンマによる打撃試験で 得たセンサ応答拉よび荷重履歴の計測值を用いて実験的に 求める ${ }^{24)}$. 計測誤差の影響を小さくして高精度な变換行列 を得るために $K$ 回の打撃試験の計測情報を用いると, 変換 行列の成分は次式の最小二乗問題を解くことにより求めら れる。

$$
\operatorname{minimize}: \sum_{k=1}^{K}\left\|\left\{\tilde{\boldsymbol{p}}_{i}^{k}\right\}-\left[\tilde{F}^{k}\right]\left\{\boldsymbol{g}_{i}\right\}\right\|^{2}
$$

variables : $\left\{\boldsymbol{g}_{i}\right\}$

なお，アクセント記号 (〜) はベクトルまたは行列の成分が 実験の計測值であることを表している.

変換行列 $[G]$ は衝撃荷重の作用位置およびセンサの位置 の関数であるため, 同定領域内の任意の作用位置に扔ける 各センサの変換行列が必要となる。そこで，第 2 図 (a)の ように同定領域を格子状に分割し, 式 (5) より, 各節点上 に衝撃荷重が作用する場合の実験的変換行列をセンサごと に予め決定しておく，要素内に拝いては，第 2 図 (b) に示 すように，その要素を構成する 4 節点に扔ける実験的変換 行列と, 有限要素解析で用いられる二次元アイソパラメト リック 4 節点要素の形状関数を用いて補間する ${ }^{24)}$.

2.2 荷重位置同定 衝撃荷重の作用位置は, 各マイク ロホンへの放射音の到達時間 $T$ を用いて同定する。荷重位 置とセンサ間の距離を $r$, 音速を $v$ とすると, $i$ 番センサ と $j$ 番センサで生じる放射音の到達時間の差 $\Delta T_{i j}$ は次式 のように表される。

$$
\Delta T_{i j}=T_{j}-T_{i}=\frac{r_{j}}{v}-\frac{r_{i}}{v}
$$

計測した放射音の到達時間の差 $\Delta \tilde{T}_{i j}$ と, 式 (6) から計算 される時間差の残差二乗和を最小化することにより荷重位 置を同定できる。

$$
\begin{aligned}
& \text { minimize }: \sum_{i=1}^{I-1} \sum_{j=i+1}^{I}\left\{\Delta \tilde{T}_{i j}-\left(\frac{r_{j}}{v}-\frac{r_{i}}{v}\right)\right\}^{2} \\
& \text { variables }: x_{\mathrm{F}}, y_{\mathrm{F}}
\end{aligned}
$$

式 (7) の無制約最小化問題を解くにあたり, 最適化手法と しては共役勾配法（Fletcher-Reeves 法）を, 一次元探索 には黄金分割法を用いた。

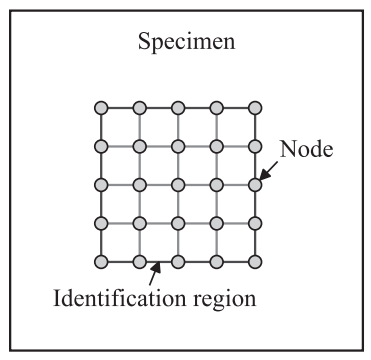

(a)

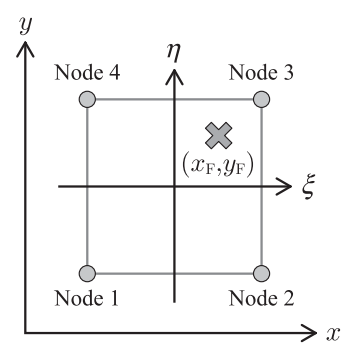

(b)
第 2 図 実験的変換行列の作成 (a) および補間 (b) 
なお, 本研究ではマイクロホンの数は $I=4$ を用いてお り，各マイクロホンにおける放射音の到達時間の計測值は 予め実験的に設定した閾值によって決定する。 また，音速 $v$ は室内の摂氏温度 $T_{\text {air }}$ を計測して次式より求める。

$$
v=\sqrt{\frac{\gamma R}{M}\left(T_{\text {air }}+273.15\right)}
$$

ここで, $\gamma$ は比熱比, $R$ は気体定数, $M$ はモル質量である.

2.3 荷重履歴同定 荷重履歴は, 各時刻 $t_{n}(n=1,2$, ...) に招ける音圧の計測值と, 実験的変換行列を用いて式 (1) から求められる計算值の残差 2 乗和を最小化すること により同定する。第 3 図に示すように，荷重の情報が放射 音として $i$ 番目マイクロホンに伝わるには $T_{i}$ の時間を要 するため, 荷重履歴を同定する時間を $t_{N^{*}}$ とすると, 時刻 $t=t_{N *}+T_{i}$ までの音圧計測情報が必要になる。したがっ て, 荷重履歴同定式は次式のように表される.

$$
\begin{aligned}
\text { minimize } & : \sum_{i=1}^{I}\left\|\left\{\tilde{\boldsymbol{p}}_{i}^{*}\right\}-\left[G_{i}^{*}\right]\left\{\boldsymbol{f}^{*}\right\}\right\|^{2} \\
\text { subject to } & : f(t) \geq 0 \\
\text { variables } & :\left\{\boldsymbol{f}^{*}\right\}
\end{aligned}
$$

ただし，

$$
\begin{aligned}
\left\{\tilde{\boldsymbol{p}}_{i}^{*}\right\}= & {\left[\begin{array}{llll}
\tilde{p}_{i}\left(t_{1}\right) & \tilde{p}_{i}\left(t_{2}\right) & \cdots & \tilde{p}_{i}\left(t_{N^{*}+\lambda_{i}}\right)
\end{array}\right]^{\mathrm{T}}, } \\
\left\{\boldsymbol{f}^{*}\right\}= & {\left[\begin{array}{llll}
f\left(t_{1}\right) & f\left(t_{2}\right) & \cdots & f\left(t_{N^{*}}\right)
\end{array}\right]^{\mathrm{T}}, } \\
{\left[G_{i}^{*}\right]=} & {\left[\begin{array}{cccc}
g_{i, 1} & 0 & \cdots & 0 \\
g_{i, 2} & g_{i, 1} & \ddots & \vdots \\
\vdots & \vdots & \ddots & 0 \\
g_{i, N^{*}} & g_{i, N^{*}-1} & \cdots & g_{i, 1} \\
\vdots & \vdots & & \vdots \\
g_{i, N^{*}+\lambda_{i}} & g_{i, N^{*}-1+\lambda_{i}} & \cdots & g_{i, 1+\lambda_{i}}
\end{array}\right] }
\end{aligned}
$$

ここで, $\lambda_{i}=T_{i} / \Delta t_{\mathrm{s}}$ である. 衝撃荷重が平板に対して引 張りとならないよう非負制約を導入しているため, 式 (9)

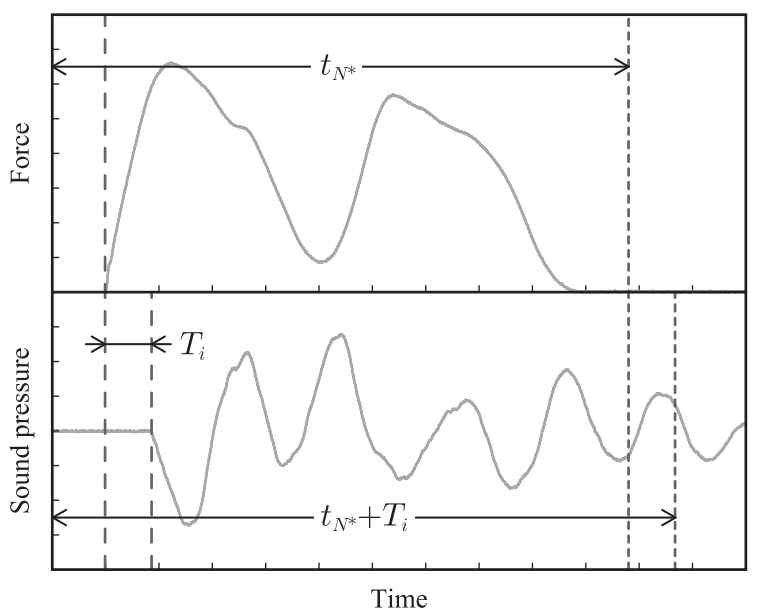

第 3 図 荷重履歴および放射音圧
を解く最適化手法としては二次計画法を用いる.

\section{3. 実 験 概 要}

3.1 試験片および実験装置 同定実験で試験片として 用いる CFRP 積層板は, 第 4 図に示すような, 積層構成が $\left[0{ }_{2} / 45_{2} /-45_{2} / 90_{2}\right]_{\mathrm{S}}$ の擬似等方性積層板である. ここで, CFRP 単層板の厚さは $0.125 \mathrm{~mm}$ であり, 繊維配向角 $\theta$ の $0^{\circ}$ 方向は $x$ 軸と一致しているものとする。境界条件は四 隅固定支持とし，平板の四隅をそれぞれ治具により $35 \mathrm{~mm}$ 四方固定した。

実験装置の構成を第 5 図に示す。インパルスハンマ(小 野測器，GK-3100）によって試験片に衝撃荷重を作用さ せ, 放射音圧を $1 / 2$ インチ計測用マイクロホン (小野測器, MI-1234）で計測する。マイクロホンからの信号はプリア ンプ (小野測器, MI-3110) と 2 チャンネルセンサアンプ (小野測器, SR-2200) を介してからデジタルオシロスコー プ (キーエンス, GR-7000) で記録する。この計測情報を 用いてパソコンにより衝撃荷重同定を行う。なお，インパ ルスハンマ出力も実験的変換行列の作成や荷重履歴同定結 果との比較のために計測する.

インパルスハンマの先端チップは，ゴム製のソフトチッ プとプラスチック製のハードチップの 2 種類を使い分けた. 4 式のマイクロホンは, 各々の先端の中心が第 1 表に示す 1 辺の長さが $60 \mathrm{~mm}$ である正四面体の各頂点の位置と一致 するよう配置した。 マイクロホンとインパルスハンマから

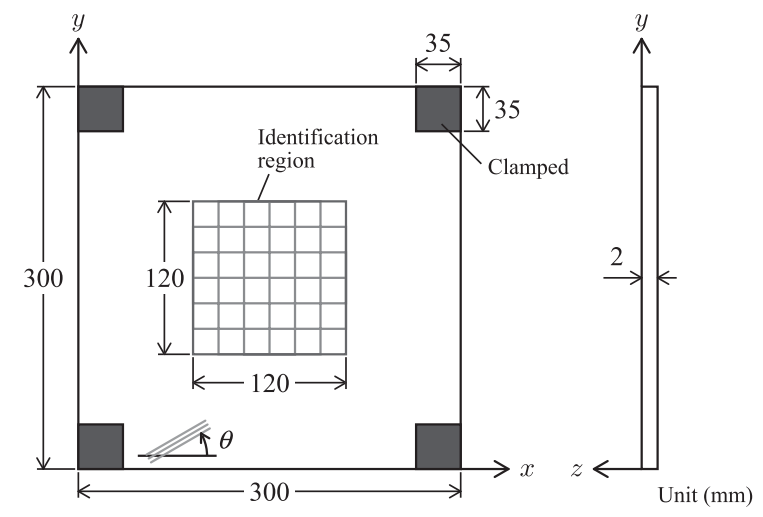

第 4 図 試験片概略図

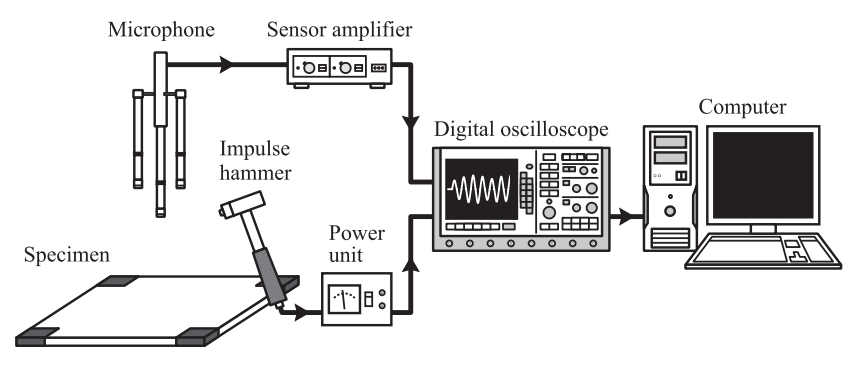

第 5 図 実験装置の構成

第 1 表 マイクロホンの配置（単位： $\mathrm{mm}$ )

\begin{tabular}{cccc}
\hline Microphone 1 & Microphone 2 & Microphone 3 & Microphone 4 \\
\hline$(150,150,248)$ & $(185,150,297)$ & $(133,180,297)$ & $(133,120,297)$
\end{tabular}


得られる音圧と荷重を計測する時間間隔は $0.1 \mu \mathrm{s}$ とした。

3.2 衝撃荷重同定 第 4 図に示すように, 衝撃荷重の 同定領域は 1 辺が $120 \mathrm{~mm}$ の正方形領域とし, 実験的変換 行列を求めるにあたっての分割は $20 \mathrm{~mm}$ 間隔とした，変換 行列は, ソフトチップを用いて得た荷重・音圧計測情報か ら作成したものと, ハードチップによるものとの 2 種類を 作成した。 なお，式 (5)において, 各節点につき行う打撃 試験の回数は $K=5$ とした，荷重位置同定で用いる音速 $v$ は, 温湿度計 (LUFFT, E200) で計測した実験時の室温 $T_{\text {air }}=24.4^{\circ} \mathrm{C}$ と式 $(8)$ より $346.04 \mathrm{~m} / \mathrm{s}$ と求めた.

3.3 騒音環境下における音圧計測情報 騒音がある状 況下での衝撃荷重同定では, 静寂な実験室内で計測された 衝撃荷重作用時の放射音圧 $\tilde{p}(t)$ にパソコンで発生させたホ ワイトノイズを加えることにより, 騒音環境下での各マイ

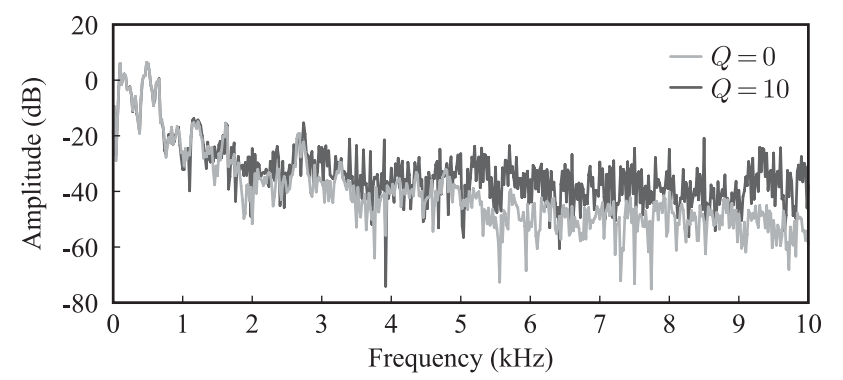

(a) ソフトチップ

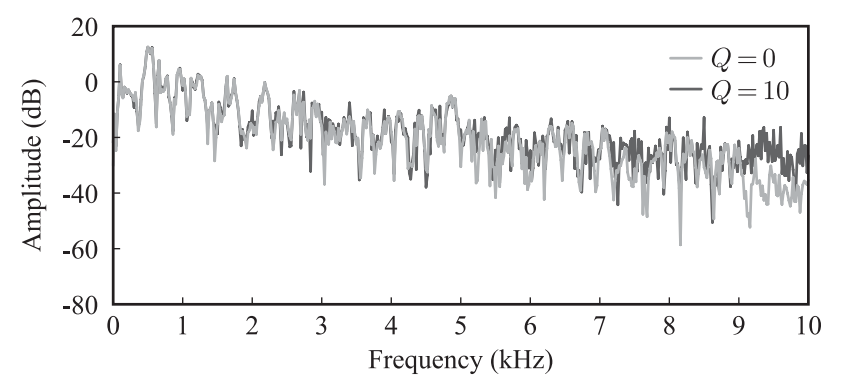

(b) ハードチップ

第 6 図 音圧計測情報に含まれる周波数成分: $\left(x_{\mathrm{F}}, y_{\mathrm{F}}\right)=(150,150)$, 1 番マイクロホン
クロホンの音圧計測情報 $\tilde{p}_{\text {noise }}(t)$ を模擬した.

$$
\tilde{p}_{\text {noise }}(t)=\tilde{p}(t)+\tilde{p}_{\max } \times \frac{Q}{100} \times w(t)
$$

ここで， $\tilde{p}_{\max }$ は計測時間内における $\tilde{p}(t)$ の最大音圧で ある、 $Q$ は騒音の大きさを指定する変数であり, 本研究で は $Q=2,4,6,8,10$ の 5 通りを検討した。 また, $w(t)$ は $-1 \leq w(t) \leq 1$ の一様乱数である.

第 6 図に式 (11) より求めた音圧計測情報の FFT 解析結 果の一例を示す．騒音がない場合の音圧 $(Q=0)$ にホワイ トノイズを加えることにより, 広带域の周波数に対してノ イズを導入できていることがわかる。

\section{4. 同定結果および考察}

4.1 騷音がない場合 まずは, 静寂な実験室内で行った 衝撃荷重同定実験の結果について述べる。第 7 図に, マイ クロホンへの放射音の到達時間を用いた荷重位置同定の結 果を示す。図において，引は荷重位置の同定結果を，回は 計測值を表している。同定実験はソフトチップおよびハー ドチップの各先端チップにつき 36 の位置で行った。眓より, 先端チップの剛性に関係なく荷重位置が精度良く同定され ていることがわかる. 同定結果と計測值との間の距離を同 定誤差とすると, ソフトチップでは平均で $4.7 \mathrm{~mm}$, 最大で $8.9 \mathrm{~mm}$ であった. また, ハードチップにおいては, 平均誤 差は $2.9 \mathrm{~mm}$, 最大誤差は $6.0 \mathrm{~mm}$ であった。

荷重位置同定誤差が最大となった第 7 図中の点 $\mathrm{A}$ および 点 B の荷重履歴同定結果をそれぞれ第 8 図および第 9 図に 示す。なお, 荷重履歴同定はソフトチップ製の実験的変換 行列を用いる場合とハードチップ製の場合の 2 通りで行っ た. 荷重履歴同定の時間間隔は $20 \mu \mathrm{s}$, 同定時間は $14 \mathrm{~ms}$ と した。第 8 図より, ソフトチップによる衝撃荷重は, 変換 行列の作成に用いた先端チップの種類によらず精度良く荷 重履歴が同定されていることがわかる。一方，ハードチッ プによる衝撃荷重の場合は, 同じハードチップで作成した 変換行列でしか良好な同定結果が得られないことが第 9 図

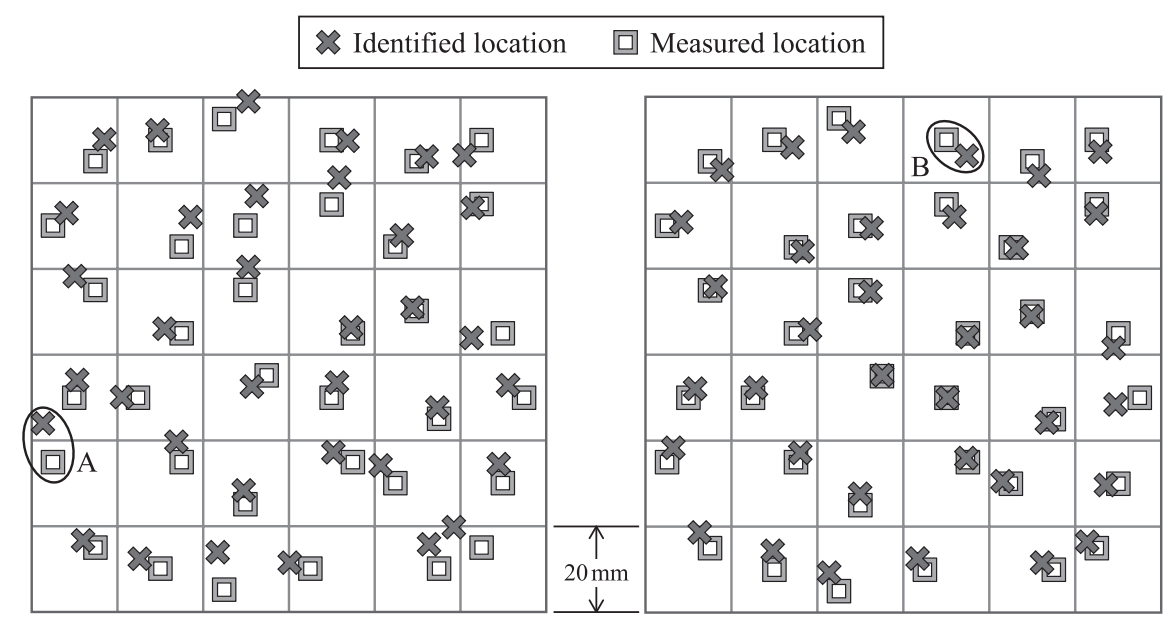

(a) ソフトチップ

(b) ハードチップ

第 7 図＼cjkstart騒音がない環境下での荷重位置同定結果 


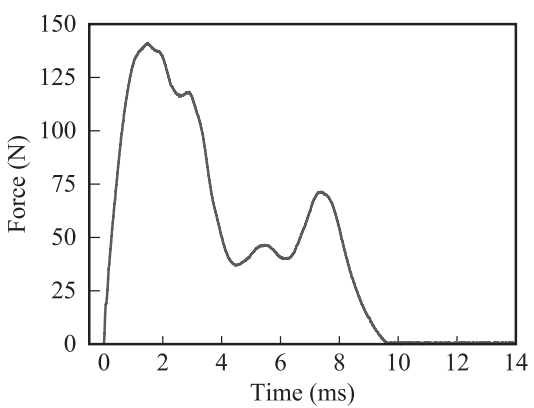

(a) 計測值

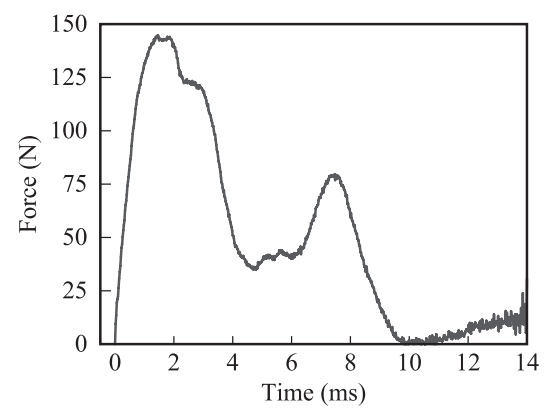

(b) 同定結果 (変換行列 : ソフトチップ)

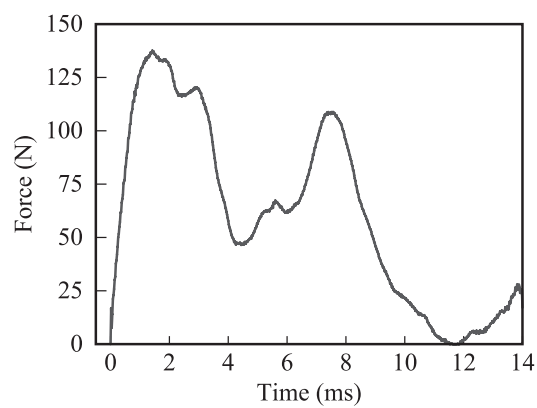

(c) 同定結果 (変換行列 : ハードチップ)

第 8 図 騒音がない環境下での荷重履歴同定結果（衝撃荷重：ソフトチップ, 点 $\mathrm{A}$ ）

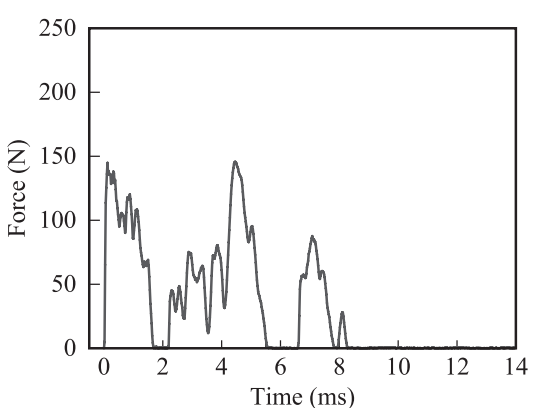

(a) 計測值

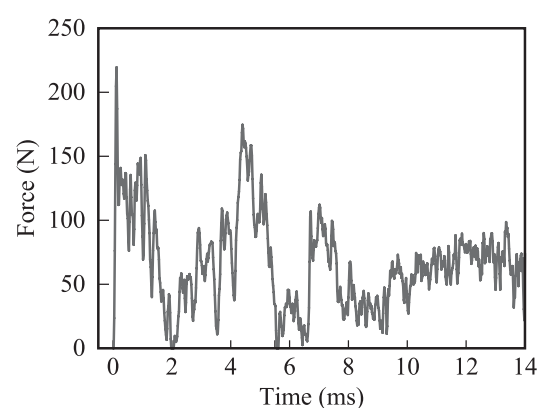

(b) 同定結果（変換行列：ソフトチップ）

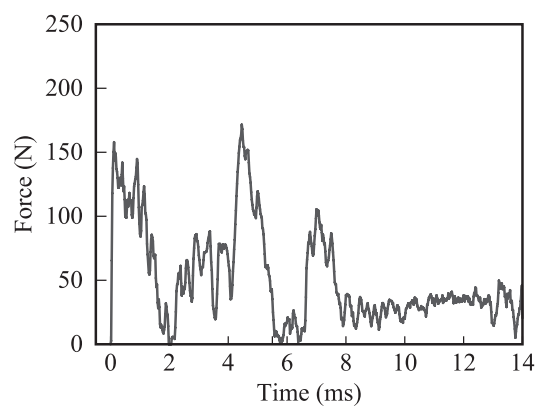

(c) 同定結果 (変換行列 : ハードチップ)

第 9 図 騒音がない環境下での荷重履歴同定結果（衝撃荷重：ハードチップ, 点 B )

第 2 表 騒音がない場合における荷重履歴同定誤差

\begin{tabular}{ccrrr}
\hline \multicolumn{2}{c}{ Impulse hammer tip } & & \multicolumn{2}{c}{ Error of identified force } \\
\cline { 1 - 2 } \cline { 5 - 5 } Identification & Transfer matrix & & Average & Maximum \\
\hline Soft tip & Soft tip & & $1.9 \%$ & $5.4 \%$ \\
Soft tip & Hard tip & & $3.1 \%$ & $9.8 \%$ \\
Hard tip & Soft tip & & $36.4 \%$ & $63.4 \%$ \\
Hard tip & Hard tip & & $5.8 \%$ & $17.2 \%$ \\
\hline
\end{tabular}

よりわかる．第 6 図に示したソフトチップ・ハードチップ で打撃した場合の音圧計測情報に含まれる周波数成分を比 較すると,ソフトチップの場合に㧍ける放射音圧には低周 波数の成分しか含まれていないのに対し, ハードチップで は低周波数から高周波数までの幅広い带域の成分が含まれ ていることがわかる。よって, ソフトチップの荷重・音圧 計測情報から作成した変換行列を用いてハードチップの衝 撃荷重を同定した場合，第 9 図 (b)のように, ソフトチッ プの変換行列に情報が含まれていない高周波数の成分がノ イズとして荷重履歴同定結果に現れ，同定精度が悪くなる.

荷重履歴の同定精度を定量的に評価するため, 同定誤差 を次式のように定義する。

$$
E_{\mathrm{F}}=\frac{\left|f_{\mathrm{m}}^{\max }-f_{\mathrm{id}}^{\max }\right|}{\left|f_{\mathrm{m}}^{\max }\right|}
$$

ここで, $f_{\mathrm{m}}^{\max }$ および $f_{\mathrm{id}}^{\max }$ は, 荷重の計測值および同定 值の同定時間内に㧈けるそれぞれの最大值である。第 2 表 に, 同定実験を行った全 36 点での荷重履歴同定誤差の平均 值および最大值を示す。

先端チップの剛性によらず高精度な荷重履歴同定結果を 得るには, 広带域の周波数成分が含まれるハードチップの 荷重・音圧計測情報から作成した変換行列を用いることが
重要であることがわかる.

以上の結果から, 非接触型センサであるマイクロホンで 計測した振動放射音を計測情報とする本同定法により，構造 物に貼付したPZT 圧電センサを用いる衝撃荷重同定法 ${ }^{16)}$ と同等の精度で, 荷重位置掞よび荷重履歴を同定できるこ とが明らかとなった。

4.2 騒音がある場合 衝撃荷重作用時の放射音圧を用 いる本同定法の場合, その有用性を検討するうえで騒音環 境が同定精度に及ぼす影響は重要な検討項目である。そこ で, 式 (11)により模擬した騒音環境下における音圧計測情 報を用いて, 前節の騒音がない場合と同じ全 36 点で衝撃 荷重同定を行った。

第 10 図に, 騒音の大きさを $Q=10$ とした場合の騒音 環境下での荷重位置同定結果を示す。なお，図の見易さを 考慮して第 10 図には 12 点の結果のみを示した。 図より, 騒音がない場合の第 7 図と比べて両先端チップとも荷重 位置同定精度が大きく低下していることがわかる，騒音に 含まれる高周波数領域の雑音は, 閾値を用いて検出される 各マイクロホンに扔ける衝撃音の到達時間に誤差を生じさ せ, この誤差が荷重位置同定誤差の原因となる。 そこで, 本 研究では周波数フィルタを用いて高周波数領域の雑音を低 減することで騒音環境下に㧍ける荷重位置同定精度の向上 を図る、衝撃音の情報が損なわれないよう第 6 図で示した 放射音圧に含まれる周波数成分を考慮し，ローパスフィル 夕の遮断周波数は $10 \mathrm{kHz}$ とする。第 11 図に, 周波数フィ ルタを導入した場合の荷重位置同定結果を示す。第 10 図と の比較から, ローパスフィルタで高周波数領域の雑音を低 減することにより, 騒音環境下でも精度良く荷重位置が同 


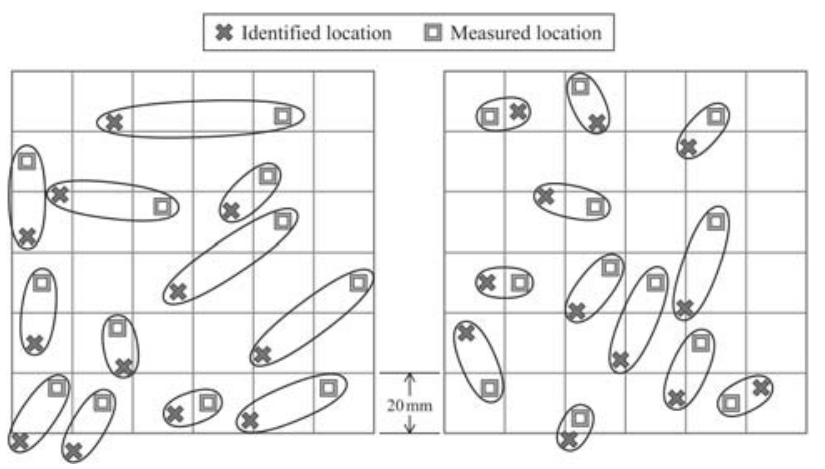

(a) ソフトチップ

(b) ハードチップ

第 10 図 荷重位置同定結果（騒音の大きさ $Q=10$ の場合）

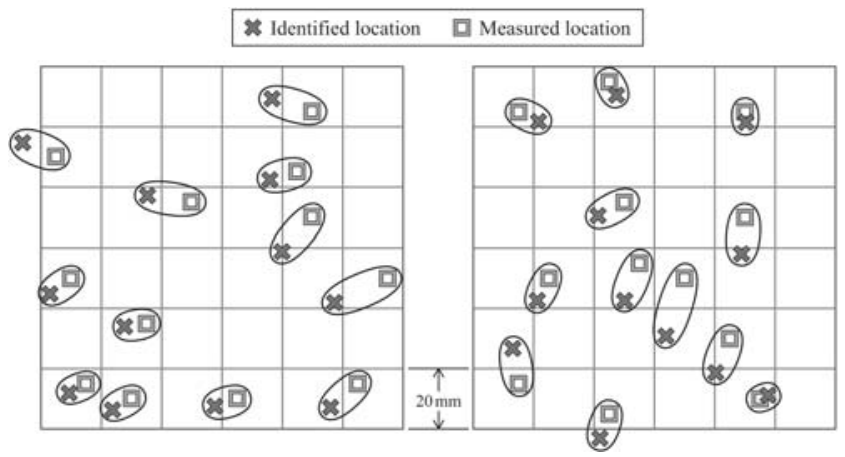

(a) ソフトチップ

(b) ハードチップ

第11図 ローパスフィルタを用いた荷重位置同定結果（騷音の大き さ $Q=10$, 遮断周波数 $10 \mathrm{kHz}$ の場合）

定可能となることがわかる.

第 12 図に, 騒音の大きさ $Q$ と荷重位置同定誤差の関倸 を, フィル夕使用の有無で比較して示す. 図において, マー カーは同定誤差の平均值を, 垂線は誤差の範囲を表してい る. 図より, 両先端チップとも, 騒音が大きくなるに伴って 位置同定誤差も大きくなるが, 周波数フィルタで騒音の高 周波数成分を除去することで誤差が低減されることがわか る。なお，ソフトチップのほうが騒音による同定精度の低 下，㧍よび，フィル夕を導入した際の同定精度の向上がハー ドチップの場合よりも著しいが，これは各々の先端チップ で打撃した場合の放射音圧に含まれる周波数成分の違いに よるものと考えられる.ソフトチップで打撃した場合, 平 板の振動は低次の振動モードが支配的となるため, 第 13 図 に示すように，放射音圧の立ち上がりがハードチップの場 合と比べて緩やかとなる。このため, 高周波数領域の雑音 があると, ソフトチップのほうが閾値で検出される放射音 の到達時間の誤差が大きくなり, 結果的に位置同定誤差も 大きくなる，ゆえに，周波数フィル夕を導入した際の効果 もソフトチップのほうが大きくなる.

騒音の大きさ $Q$ と荷重履歴同定誤差との関係を第 14 図 に示す。なお，ここでの荷重履歴同定はハードチップで作 成した実験的変換行列を用いて行った。第 14 図 (a)より, 衝撃音に含まれる高周波数成分が小さいソフトチップでは, 騒音の大きさや周波数フィルタの有無で荷重履歴同定誤差

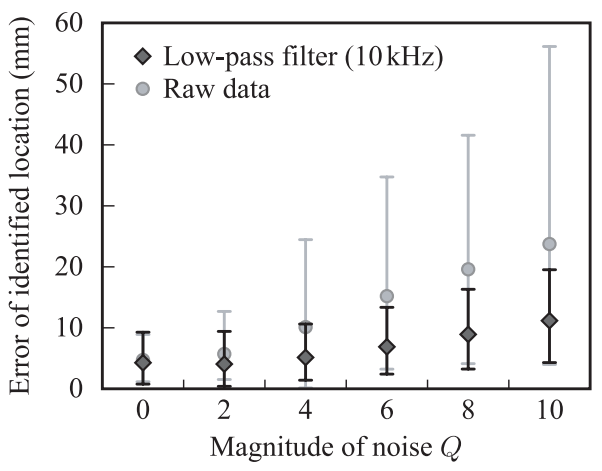

(a) ソフトチップ

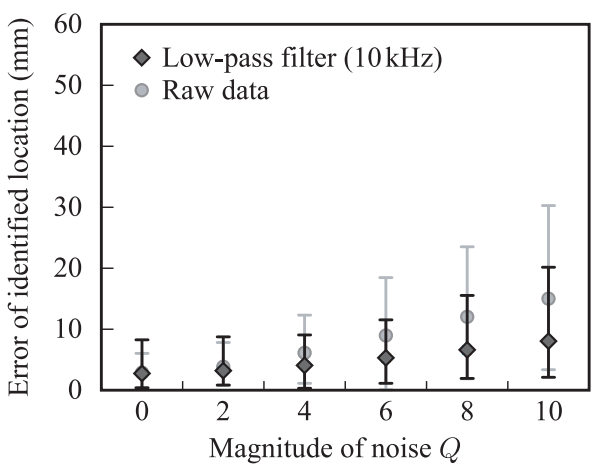

(b) ハードチップ

第 12 図 騒音と荷重位置同定誤差の関係

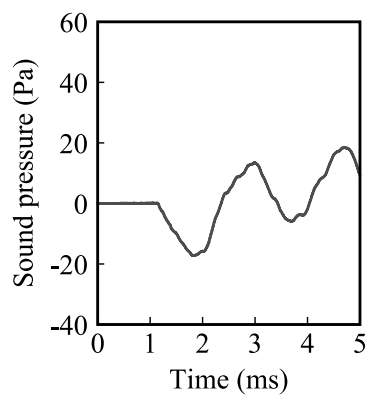

(a) ソフトチップ

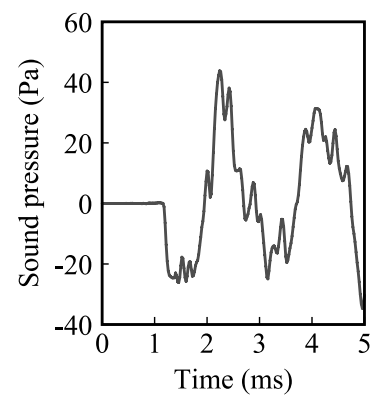

(b) ハードチップ
第 13 図 平板中央を打撃した場合の 1 番マイクロホンに扔ける音圧 履歴

が大きく変動しないことがわかる，一方で，衝撃音の高周 波数成分が大きいハードチップの場合は，騒音環境下にお ける荷重履歴同定精度が周波数フィル夕の有無に大きく依 存することが第 14 図 (b)よりわかる.

以上の結果から, 周波数フィルタを導入して高周波数領 域の雑音を除去することで，騒音環境化においても本同定 法により良好な荷重位置・荷重履歴の同定結果が得られる ことが示唆された.

5. 結言

本研究では, 非接触型センサによって構造物に作用する 衝撃荷重を同定する手法の構築を目的として, マイクロホ ンで計測した放射音圧を用いる荷重位置・荷重履歴同定法を 検討した。なお，提案した同定法は構造物の解析モデルを必 要とせず実験データのみで構築可能な実験的同定法である. 


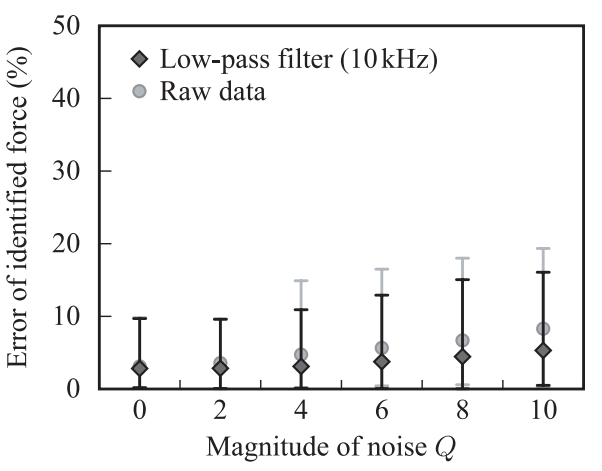

(a) ソフトチップ

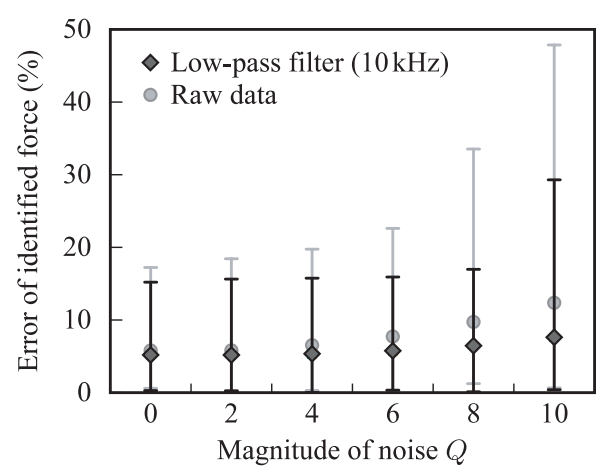

(b) ハードチップ

\section{第 14 図 騒音と荷重履歴同定誤差の関係}

本同定法の妥当性を検証するため, 擬似等方性の CFRP 積 層板を対象に，騒音のない静寂な環境下で衝撃荷重同定実 験を行った。その後，騒音がある場合における本同定法の 精度について検証した。 その結果得られた結論は以下のと おりである。

・騒音がない場合においては, 衝撃体の剛性に関係なく, 本 同定法により衝撃荷重の作用位置および荷重履歴が同定 可能であり，精度も貼付型の PZT 圧電センサを用いた 従来の手法と比べて遜色がないことがわかった。

・騒音がある場合においても良好な荷重位置・荷重履歴の同 定結果を得るためには，周波数フィルタを用いて高周波数 領域の雑音を低減することが有効であることがわかった。

\section{参 考 文 献}

1) Abrate, S.: Impact on Composite Structures, Cambridge University Press, New York, 1998.

2) Inoue, H., Harrigan, J. J. and Reid, S. R. : Review of Inverse Analysis for Indirect Measurement of Impact Force, Appl. Mech. Rev., 54 (2001), pp. 503-524.

3) Chang, C. and Sun, C. T. : Determining Transverse Impact Force on a Composite Laminate by Signal Deconvolution, Exp. Mech., 29 (1989), pp. 414-419.

4) Wu, E., Yeh, J. C. and Yen, C. S. : Identification of Impact Forces at Multiple Locations on Laminated Plates, AIAA J., 32 (1994), pp. 2433-2439.

5) Jones, R. T., Sirkis, J. S. and Friebele, E. J. : Detection of
Impact Location and Magnitude for Isotropic Plates Using Neural Networks, J. Intell. Mater. Syst. Struct., 7 (1997), pp. 90-99.

6) 狼嘉彰, 田中秀樹 : 宇宙機に働いた衝撃力と位置の推定, 日本 機械学会論文集 C 編， 63 (1997), pp. 4246-4252.

7）小野嵪徹, 関根英樹 : 矩形複合材積層板上に作用する点衝撃の位 置および荷重履歴の同定に関する実験的検証，日本航空宇宙学会 論文集, 50 (2002), pp. 236-241.

8) Adams, R. and Doyle, J. F.: Multiple Force Identification for Complex Structures, Exp. Mech., 42 (2002), pp. 25-36.

9) Lee, S. K., Banerjee, S. and Mal, A. : Identification of Impact Force on a Thick Plate Based on the Elastrodynamic and High-Order Time-Frequency Analysis, J. Mech. Eng. Sci., 221 (2007), pp. 1249-1263.

10) Tracy, M. and Chang, F. K. : Identifying Impacts in Composite Plates with Piezoelectric Strain Sensors, Part II: Experiment, J. Intell. Mater. Syst. Struct., 9 (1998), pp. 929-937.

11) Seydel, R. and Chang, F. K.: Impact Identification of Stiffened Composite Panels: I. System Development, Smart Mater. Struct., 10 (2001), pp. 354-369.

12）田島賢典, 松本 賢, 福永久雄：PZT 圧電センサによる CFRP 積層板の衝撃荷重同定（第 2 報，実験による検証），日本機械学 会論文集 A 編, 70 (2004), pp. 1747-1754.

13) Wang, B., Takatsubo, J., Akimune, Y. and Tsuda, H. : Development of a Remote Impact Damage Identification System, Struct. Control Health Monit., 12 (2005), pp. 301-314.

14）海埜孝夫, 三浦裕樹, 杉本 直, 亀山正樹, 胡寧, 福永久雄： 多点荷重を受けるCFRP 補強パネルの実験的衝撃荷重同定, 日 本複合材料学会誌, 35 (2009), pp. 106-111.

15) Park, J., Ha, S. and Chang, F. K. : Monitoring Impact Events Using a System-Identification Method, AIAA J., 47 (2009), pp. 2011-2021

16）跡部哲士, 胡 寧, 福永久雄 : 実験的変換行列を用いた平板の 実時間衝撃荷重同定, 日本航空宇宙学会論文集, 60 (2012), pp. $48-55$.

17) Gaul, L. and Hurlebaus, S. : Determination of the Impact Force on a Plate by Piezoelectric Film Sensors, Arch. Appl. Mech., 69 (1999), pp. 691-701.

18) Akhavan, F., Watkins, S. E. and Chandrashekhara, K. : Prediction of Impact Contact Forces of Composite Plates Using Fiber Optic Sensors and Neural Networks, Mech. Compos. Mater. Struct., 7 (2000), pp. 195-205.

19）水口 周, 水谷忠均, 秋野 望, 武田展雄, 筒井寛明, 平野憲芳, 木元順一, 越岡康弘 : 多重化 FBG 光ファイバセンサの動ひずみ 計測による CFRP フォームコアサンドイッチ構造の衝撃同定, 日本航空宇宙学会論文集，59 (2011), pp. 212-221.

20）辻 知章, 川田祐嗣, 鈴木喜浩, 山口友康, 野田直剛：被衝撃体 からの放射音による衝撃力の同定（逆問題解析を用いた非接触測 定による同定実験), 日本機械学会論文集 A 編, 65 (1999), pp. 701-707.

21）辻 知章, 栗本貴文, 渋谷寿一：FEM 解析を併用した放射音圧 測定による平板の衝撃力の同定, 日本機械学会論文集 A 編, 74 (2008), pp. 858-863.

22) Tsuji, T., Kurimoto, T. and Shibuya, T.: An Identification Method of the Time Dependence of the Impact Force by Using Acoustic Response and FEM Analysis, Mechanics and Model-Based Control of Smart Materials and Structures, Springer, New York, 2010, pp. 173-192.

23) 辻 知章, 伊藤康司, 嶋田英昭, 富永裕也 : 放射音測定と FEM 解 析を用いた衝撃位置, 衝撃力, 被衝撃体の縦弾性係数, 衝撃半徍 の同定，日本機械学会論文集 $\mathrm{A}$ 編， 77 (2011), pp. 1433-1443.

24）宮澤英晃, 杉本 直, 胡寧, 福永久雄 : CFRP 複合材構造の 実験的衝撃荷重位置·履歴同定, 日本複合材料学会誌, 33 (2007), pp. 87-94. 